\title{
IMPLEMENTASI MODEL PEMBELAJARAN PROBLEM BASED LEARNING DALAM MENINGKATKAN PEMAHAMAN MATA PELAJARAN FIQIH KELAS VII MTs
}

\author{
Saeful Anam ${ }^{1}$ dan Ahmad Amiq Fahman ${ }^{2}$ \\ ${ }^{1,2}$ Institut KeislamanAbdullah Faqih (INKAFA) Gresik \\ amiqfahman25@gmail.com
}

\begin{abstract}
Penelitian ini mengkaji Implementasi Model Pembelajaran Problem Based Learning dalam meningkatkan pemahaman mata pelajaran Fiqih Kelas VII di MTs Mambaus Sholihin Gresik. Jenis penelitian ini adalah penelitian lapangan (field Research) yang akan dilaksanakan di MTs Mambaus Sholihin, Sedangkan pendekatan yang digunakan adalah pendekatan kualitatif dengan metode deskriptif kualitatif. Hasli penelitian menyimpulkan bahwa model pembelajaran PBL yang di terapkan di MTs Mambaus Sholihin telah berjalan sesuai teori dan definisi meski agak sedikit berbeda dalam langkahlangkah. Namun begitu, esensi dari langkah-langkah PBL yang di lakukan para guru Fiqih MTs Mambaus Sholihin tetaplah sama dengan esensi yang di rumuskan para ahli yakni bisa melakukan proses pembelajaran berdasarkan masalah dan menuntut peserta didik lebih aktif dalam berpartisipasi dalam proses pembelajaran. Suatu proses pembelajaran apapun modelnya, para guru di tuntut harus lebih kreatif, inovatif dan sebisa mungkin membuat siswa bahagia dalam mengikuti proses pembelajaran. Begitu juga dalam menerapkan model pembelajaram PBL ini, selain harus kreatif, inovatif dan sabar, guru juga harus menyiapkan materi seringkas mungkin dan menyiapkan masalah-masalah yang dapat merangsamg siswa agar semangat dalam mengikuti proses pembelajaran.
\end{abstract}

Keywords: Implementasi, Model Problem Based Learning, Pemahaman, MTs Mambaus Sholihin Gresik 


\section{Pendahuluan}

Lembaga pendidikan adalah salah satu harapan besar bagi negeri ini agar bisa bangkit dari keterpurukan dalam semua aspek kehidupan. Bangsa yang di landa krisis sejak 1997 sampai sekarang belum mampu keluar dari krisis multidemensional ini membutuhkan kader-kader muda yang andal dan melek ilmu pengetahuan dan teknologi modern. Di pundak mereka lah, kejayaan bangsa di pertaruhkan. ${ }^{1}$ Untuk bisa mencetak generasi muda yang unggul dan martabat maka di perlukanlah pendidikan yang sehat, baik dan benar. Dalam hal ini, guru adalah aktor utama di samping orang tua dan elemen lainya untuk mensukseskan pendidikan yang di canangkan. Tanpa keterlibatan aktif guru, pendidikan kosong dari materi, esensi, dan subtansi, secanggih apapun kurikulumnya, visi, misi, kekuatan finansial, sepanjang gurunya pasif dan stagnan maka kualitas lembaga pendidikan akan merosot tajam. ${ }^{2}$

Pemerintah mendefinisikan Pendidikan sesuai Undang-Undang Republik Indonesia Nomor 20 tahun 2003 tentang Sistem Pendidikan Nasional Pasal 1 adalah usaha sadar dan terencana untuk mewujudkan suasana belajar dan proses pembelajaran agar peserta didik secara aktif mengembangkan potensi dirinya untuk memiliki kekuatan spritual keagamaan, pengendalian diri, kepribadian, kecerdasan, akhlak mulia, serta ketrampilan yang di perlukan dirinya, masyarakat, bangsa dan negara. ${ }^{3}$

Secara tidak langsung pendidikan yang di harapakan pemerintah adalah perencenaan proses pembelajaran yang berpusat pada siswa (learner centered) agar siswa aktif dalam mengikuti pembelajaran bukan berpusat pada guru (teacher centered. Fakta yang ada menunjukkan, banyak guru di negeri ini tidak sesuai dengan harapan di atas. Mereka belum mencerminkan diri guru ideal dan inovatif yang siap mendidik siswa dengan profesionalisme dan optimisme. Kapasitas intelektual yang rendah, kedisiplinan yang lemah, semangat belajar yang hampir hilang, integritas moral yang sering menyeleweng dan dedikasi sosial yang rendah adalah potret buram sebagian guru. ${ }^{4}$

Berdasarkan hasil analisis penelitian terhadap rendahnya pemahaman siswa, di sebabkan dominanya proses pembelajaran konvensional. Pada pembelajaran sekarang ini suasana kelas cenderung teacher-centered sehingga siswa

\footnotetext{
${ }^{1}$ Jamal Ma'mur Asmani, 2013, Tips menjadiguruinspiratif, kreatif dan inovatif, Jogjakarta: Diva-press, hlm, 5.

${ }^{2}$ Ibid, 5 .

${ }^{3}$ Undang-undang Republik Indonesia Nomor 20 Tahun 2003 Tentang Sistem Pendidikan Nasional Tahun 2003, hlm, 1 .

${ }^{4}$ Jamal Ma'mur Asmani, Tips menjadiguru ..., hlm, 6.
} 
menjadi pasif. Meskipun demikian, guru lebih suka menerapkan model tersebut sebab tidak memerlukan alat dan bahan praktek. Cukup menjelaskan konsepkonsep yang ada pada buku ajar atau refrensi lain. Dalam hal ini, siswa tidak di ajarkan strategi belajar yang dapat memahami bagaimana belajar, berpikir, dan memotivasi diri sendiri (self motivation), padahal aspek-aspek tersebut kunci keberhasilan dalam proses belajar mengajar di kelas. ${ }^{5}$

Madrasah Tsanawiyah Mambaus Sholihin merupakan Madrasah Tsanawiyah debgan siswa terbanyak di Kabupaten Gresik. Madrasah ini di bawah naungan pondok pesantren Mabaus Sholihin. Pondok ini di asuh oleh seorang kiai kharismatik yang bernama Kh Masbuhin Faqih dan telah memiliki ribuan siswa dan alumni yang tersebar di seluruh pelosok negeri. Beliau adalah alumni pondok modern Darussalam Gontor dan Pondok Pesantren Langitan sehingga pondok yang beliau asuh memadukan antara kurikulum modern dan salaf. Tentunya ini sangat baik apabila bisa berjalan dengan efektif dan efisien.

Madrasah ini memiliki keunggulan dalam hal memahami kitab kuning dan berbicara bahasa Inggris dan Arab. Karena di Madrasah ini seluruh siswa di tuntut untuk mampu memahami kitab kuning khususnya fiqih, bahasa Inggris dan Arab. Namun seiring berjalanya waktu dan seiring bertambahnya jumlah siswa, yang otomatis semakin banyak perbedaan karakter-karakternya, serta kurangnya tenaga pengajar yang mumpuni dan fasilitas yang terkesan apa adanya ini sedikit demi sedikit mengalami kemunduran dalam hal siswa saat memahami fiqih. Kebanyakan mereka mengeluh sangat sulit memahami pemahaman dari kitabkitab fiqih yang kurikulumnya sudah di tentukan pesantren. Di tambah lagi dengan cara mengajar guru yang masih mengandalkan cara lama. Yakni cenderung guru aktif menyampaikan materi dan siswa hanya pasif mendengarkan. Dalam memahami fiqih, memang kalau hanya sebatas toritis tanpa ada praktek yang sesuai dengan kehidupann sehari-hari itu cenderung faham tapi mudah lupa karena yang di sampaikan hanya materi tanpa tahu cara untuk mengaplikasikanya dalam kehidupan nyata.

Berdasarkan informasi dari salah satu ustadz pondok, tingkat kemampuan siswa dalam memahami fiqih cukup memadai. Akan tetapi kemampuan siswa dalam mengaplikasikanya sehari-hari masih membutuhkan pengawasan dan perhatian. Problem based learning (PBL) adalah salah model pemeblajaran yang mengkaitkan antara masalah kehidupan sehari-hari dengan materi pelajaran agar

\footnotetext{
${ }^{5}$ Abdul Majid, 2012, Belajar dan Pembelajaran Pendidikan Agama Islam, Bandung: Remaja Rosdakarya hlm, 10.
} 
siswa dapat melakukan dari materi yang telah di sampaikan. Seorang guru dalam memilih model pembelajaran menyesuaikan dengan materi yang akan di ajarkan. Salah satu contohnya adalah model pembelajaran PBL, model yang sebenarnya sudah lama, tetapi masih relevan untuk di gunakan.dalam pembelajaran, karena pembelajaran dengan model tersebut mengajak siswa berperan aktif dan mengikuti pembelajaran dengan baik. Dengan tujuan mampu memecahkan persoialan dengan pengetahuanya. Penggunaan metode yang tepat membuat siswa muda menerima materi pembelajaran sehingga mempengaruhi pula dalam meningkatkan pemahamanya.

Berdasarkan masalah di atas penulis tertarik untuk meneliti model pembelajaran berbasis masalah yang sudah dan sedang di terapkan di salah satu kelas yang ada di pondok pesantren Mambaus Sholihin. Penulis ingin membuktikan bahwa model pembelajaran Problem based learning dapat meningkatkan proses berfikir kritis dan tajam serta bisa memudahkan siswa dalam memahami dan memecahkan suatu masalah. Sehingga menurut hemat penulis model pembelajaran ini sangat menarik untuk di teliti dan di kaji lebih mendalam terkait kemaksimalanya dan kefektifanya dalam meningkatkan pemahaman suatu mata pelajaran. Oleh karenanya penulis memilih judul " Implementasi Model Pembelajaran Problem Based Learning Dalam Meningkatkan Pemahaman Mata Pelajaran Fiqih Kelas VII MTs Mambaus Sholihin Gresik “

Adapun alasan mengapa penulis memilih siswa kelas VII ini di karenakan kelas ini adalah awal dalam segala hal dalam pembelajaran fiqih, sehingga kalau dari awal sudah baik insya allah seterusnya akan baik. Fiqih yang di maksud di sini adalah dalam aspek ubudiyah saja, karena masih awal.Dengan demikian fokus penelitian penulis adalah efektifitas PBL dalam meningkatkan pemahaman siswa kelas VII Mts Mambaus Sholihin pada materi ubudiyah.

\section{Metode Penelitian}

Jenis penelitian yang digunakan dalam penelitian ini adalah penelitian lapangan (field Research) yang akan dilaksanakan di MTs Mambaus Sholihin, Sedangkan pendekatan yang digunakan adalah pendekatan kualitatif dengan metode deskriptif kualitatif, yaitu metode penelitian yang bertujuan untuk menggambarkan secara utuh dan mendalam tentang realitas sosial dan berbagai fenomena yang terjadi di sekolah yang menjadi subyek penelitian sehingga Nampak ciri, karakter, sifat dan model dari fenomena tersebut. ${ }^{6}$

\footnotetext{
${ }^{6}$ Wina Sanjaya, 2013, Penelitian Pendidikan; Jenis, Metode, Dan Prosedur, Jakarta: Kencana, hlm. 47.
} 
Penelitian kualitatif adalah prosedur penelitian yang menghasilkan data deskriftif berupakata-kata tertulis/lisan dari orang-orang atau prilaku yang diamati. ${ }^{7}$ Adapun alasan penelitian ini menggunakan pendekatan kualitatif adalah karena dalam penelitian ini data yang dihasilkan berupa data deskriptif yang diperoleh dari data-data berupa tulisan, kata-kata dan dokumen yang berasal dari sumber atau informan yang diteliti dan dapat dipercaya.

Metode kualitatif digunakan karena beberapa pertimbangan, pertama menyesuaikan metode kualtatif lebih mudah apabila berhadapan dengan kenyaataan ganda; kedua, metode ini menyajikan secara langsung hakekat hubungan antara peneliti dan responden; ketiga, metode ini lebih peka dan lebih dapat menyesuaikan diri dengan penajaman pengaruh bersama dan terhadap polapola nilai yang dihadapi. ${ }^{8}$

Sesuai dengan judul dan latar belakang yang peneliti ajukan, maka penelitian yang di adakan termasuk Pendidikan ini merupakan suatu proses pengumpulan data secara sistematis dan intensif untuk memperoleh pengetahuan tentang implementasi model pembelajaran Problem based learning dalam meningkatkan pemahaman fiqih Kelas VII MTs Mambaus Sholihin Gresik.

\section{Pelaksanaan Problem based learning dalam meningkatan pemahaman Fiqih Kelas VII MTs Mambaus Sholihin Gresik}

Problem based learning yang di laksanakan di MTs Mambaus Sholihin adalah sebagai salah satu usaha guru dalam meningkatkan pemahaman fiqih kelas VII. Model pembelajaran ini bertujuan untuk meningkatkan kualitas peserta didik yang semakin hari semakin menurun khususnya dalam memahami mata pelajaran Fiqih. Namun pelaksanaan Problem based learning ini agak berbeda dengan teori yang di rumuskan para ahli. Sebagian ahli mengatakan bahwaProblem based learning sebagai pembelajaran yang di peroleh melalui proses menuju pemahaman akan resolusi suatu masalah.Masalah tersebut di pertemukan pertama-tama dalam proses pembelajaran. ${ }^{9}$ Pembelajaran dengan model PBL secara umum pembelajaran ini menyajikan situasi masalah yang autentik dan bermakna kepada siswa sehinnga dapat memberikan kemudahan kepada mereka untuk melakukan peneyelidikan.

\footnotetext{
${ }^{7}$ Lexy j. Moleong, 2010, Metodologi Penelitian Kualitatif, Bandung:Remaja Rosda Karya, hlm.4.

${ }^{8} \mathrm{Ibid}, \mathrm{hlm} .9-10$.

${ }^{9}$ Huda, Model-Model Pengajaran,,,, hlm 271.
}

Kariman, Volume 08, Nomor 02, Desember 2020 | 209 
Mengacu pada definisi di atas maka dapat di simpulkan guru yang menerapkan model pembelajaran ini harus selalu meningkatkan pengetahuan dan memahami masalah-masalah untuk di sampaikan ke peserta didik dan bersamasama mencari solusi dari permasalahan tersebut.

Dari pengamatan penulis, para guru di MTs Mambaus Sholihin sebagian besar telah melakukan PBL sesuai teori dan definisi, namun mereka agak berbeda dalam langkah-langkah yang sudah di rumuskan para ahli. Meski berbeda, hakikat pembelajaran yang di lakukan guru ini sesuai dengan teori meski langkah-langkah pembelajaranya berbeda. ini sesuai dengan hasil wawancara kami dengan WAKA Kurikulum MTs Mambaus Sholihin.

"Memang benar di sini pembelajaran khususnya mata pelajaran fiqih harus berdasarkan masalah. Ini bertujuan untuk agar para siswa lebih muda dalam memahami dan mengaplikasikanya dalam kehidupan sehari-sehari. Karena kalu hanya sebatas teori itu mudah faham mudah lupa."

Kalau teori mengatakan bahwa untuk melakukan model pembelajaran PBL dengan cara guru membantu peserta didik dalam mencari masalah lalu membantu siswa menyiapkan karya sesuai yang di telitinya untuk di presentasikan di depan kelas lalu di evaluasi, lain halnya yang sudah di lakukan dewan guru di MTs Mambaus Sholihin khususnya guru Fiqih. Para guru fiqih di MTs Mambaus Sholihin melakukan kegiatan belajar sama seperti biasanya, Cuma dalam menyampaikan materi para guru memberikan masalah-masalah yang terjadi di sekeliling mereka serta menyuruh peserta didik juga mencari masalah untuk di carikan jawaban dan solusinya tanpa membuat karya dan mempresentasikanya di depan kelas. Maka meski berbeda dalam langkah-langkahnya, tapi esensi yang di dapatpun sama.

Pak Subhan selaku guru yang mengampuh mata pelajaran fiqih di kelas VII MTs Mambaus Sholihin juga menuturkan bahwa

"Pembelajaran Mata pelajaran Fiqih ini sama seperti biasanya, Cuma dalam menyampaikan saya memberikan masalah-masalah yang terjadi di sekeliling mereka secara umum kemudian menyuruh peserta didik juga mencari masalah untuk di carikan jawaban dan solusinya tanpa membuat karya dan mempresentasikanya di depan kelas. Kemudian jikalau terjadi kebuuntuan dalam hal jawaban, nanti saya yang bantu mereka untuk menjawabnya. Di sini tidak diperlukan presentasi ke depan karena memang siswa-siwa masih lemah dalam hal itu." 
Menurut pengamatan penulis baik lewat wawancara atau observasi lapangan, Model pembelajaran PBL yang di lakukan oleh para guru Fiqih MTs Mambaus Sholihin adalah dengan cara peserta didik menyimak betul apa yang di sampaikan guru dan telah menyiapkan pertanyaan-pertanyaan seputar permasalahan terkait materi meskiguru sudah menyiapkan masalah-masalah itu. Sesudah guru menyampaikan materi, guru melontarkan permasalahanpermasalahan terkait materi pembelajaran kepada peserta didik. Para guru memberikan sekitar lima belas menit untuk siswa berfikir untuk mencari jawaban. Bilamana dari permasalahan tersebut peserta didik kesulitan mencari jawaban dan solusi, para guru membantunya untuk di arahakan bagaimana cara berfikirnya, kalau masih kesulitan juga, dewan guru yang akhirnya memberikan jawaban kepada peserta didik terkait masalah tadi. Seusai itu, gantian peserta didik yang merasa mempunyai masalah terkait materi di suruh untuk menyampaikanya dan mendiskusikan bersama-sama yang di awasi oleh guru. Kesimpulan ini kami buat sesuai hasil wawncara dan observasi lapanagan yang kami lakukan. Pak Afif juga salah satu guru mata pelajaran fiqih juga mengatakan hal yang hampir sama dengan apa yang di katakan pak Subhan. Beliau mengatakan

"Saya mengajar mata pelajaran fiqih ini dengan cara peserta didik menyimak betul apa yang saya sampaikan dan sebelumnya saya telah menyiapkan pertanyaanpertanyaan seputar permasalahan terkait materi. Sesudah saya menyampaikan materi, saya melontarkan permasalahan-permasalahan terkait materi pembelajaran kepada peserta didik. Lalu saya memberikan sekitar lima belas menit untuk siswa berfikir untuk mencari jawaban. Bilamana dari permasalahan tersebut peserta didik kesulitan mencari jawaban dan solusi, maka saya membantunya untuk di arahakan bagaimana cara berfikirnya, kalau masih kesulitan juga, saya yang akhirnya memberikan jawaban kepada peserta didik terkait masalah tadi. Seusai itu, gantian peserta didik yang merasa mempunyai masalah terkait materi di suruh untuk menyampaikanya dan mendiskusikan bersama-sama yang di awasi oleh guru"

Hal yang menjadi penyebab berbedanya antara langkah-langkah yang di lakukan oleh para guru di MTs Mambaus Sholihin dengan teori yang di rumuskan adalah di karenakan kapasitas peserta didik tidak memungkinkan untuk membuat karya lalu di presentasikan. Mereka masih terlalu dini untuk di beri tugas membuat karya lalu mempresentasikanya. Sehingga untuk menerapkan model pembelajaran sesuai yang di rumuskan para ahli masih terlalu sulit sehingga para menyiapkan alternatif dari itu semua. Yang terjadi selama ini di Mts Mambaus Sholihin mereka hanya di beri masalah-masalah oleh dewan guru terkait materi 
lalu di carikan bersama-sama jawaban dari itu semua di bawa komando guru tersebut sesekali di selai dengan diskusi antar teman.

Dalam pelaksanaanya, para peserta didik sangat antusias jikalau ada guru yang mengajar dengan model pembelajaran ini. Ini di bisa di buktikan ketika kami mewawancarai sebagian peserta didik kelas VII. Kami menyimpulkan dari hasil wawancara kami bahwa mereka lebih antusias dan lebih memperhatikan keterangan guru dengan model PBL ini daripada guru yang hanya mengajar dengan model pembelajaran ala kadarnya. Yakni cara mengajar dengan adagium Yang penting menyampaikan pelajaran dan selesai. Peserta didik beranggapan dengan model pembelajaran seperti ini mereka lebih mudah memahami pelajaran dan tidak mudah bosan dalam belajar karena model pembelajaran ini sangat sesuai dengan kebutuhan mereka.

Maka bisa di simpulkan bahwa model pembelajaran PBL yang di terapkan di MTs Mambaus Sholihin telah berjalan sesuai teori dan definisi meski agak sedikit berbeda dalam langkah-langkah. Namun begitu, esensi dari langkahlangkah PBL yang di lakukan para guru Fiqih MTs Mambaus Sholihin tetaplah sama dengan esensi yang di rumuskan para ahli yakni bisa melakukan proses pembelajaran berdasarkan masalah dan menuntut peserta didik lebih aktif dalam berpartisipasi dalam proses pembelajaran.

Lalu apakah penerapan model pembelajaran Problem Based Learning ini dapat meningkatkan pemahaman fiqih kelas VII MTs Mambaus Sholihin?

Menurut data yang peneliti dapatkan baik melalui observasi lapangan, wawancara dengan WAKA Kurikulum, Guru Mata pelajaran, para peserta didik, atau dokumentasi-dokumentasi, peneliti dapat menyimpulkan bahwasanya penerapan model pembelajaran problem based learning ini benar-benar memberikan dampak yang lumayan signifikan terhadap kualitas pemahaman peserta didik dalam mata pelajaran fiqih. Kesimpulan ini penulis simpulkan berdasrkan wawancara kami dengan waka kurikulum ustadz Nurul Huda, beliau berkata

"ada perbedaan yang sangat nampak anatra seorang guru yang ngajarnya hanya sebatas tekstual, tidak menerangkan pelajaran dengan keaadaan nyata dengan guru yang car mengajarnya berbasis masalah. Perbedaan mereka lebih ke tingkat pemahamn siswa".

Selain karena kegigihan dan keseriusan guru dalam mengajar juga karena ditemukan kecocokan antara model pembelajaran problem based learning dengan mata pelajaran Fiqih sehingga para guru tidak terlalu sulit dalam menerapkanya. 
Salah satu kecocokan antara PBL dengan Mata pelajaran fiqih adalah antara problem based learning dengan mata pelajaran Fiqih adalah lebih menekankan kondisi nyata daripada sekedar teori tanpa praktik di kehidupan yang sesungguhnya. Dan juga karena mata pelajaran fiqih itu lebih mudah difahami jikalau peserta didik langsung mempraktekanya dan mengamati hal baru di sekilingnya.

Indikator keberhasilan dalam peningkatan pemahaman fiqih kelas VII MTs Mambaus Sholihin adalah dengan mulai membaiknya nilai ujian tengah semester meski membaiknya bisa di katakan tidak terlalu maksimal tapi setidaknya di situ ada peningkatan kualitas pemahaman peserta didikl. Ini sesuai dengan hasil wawancara peniliti dengan para dewan guru. Di anataranya pak Afif selaku guru fiqih. Beliau menuturkan

"Memang ada perbedaan mas , antara saya ngajar sesuai konteks dan dengan menerangkan dengan mengaitkan dengan kehidupan sehari-sehari. Ini di buktikan ketika kami melakukan ulangan harian. Rata-rata nilai mereka semakin membaik meski tidak keseluruhan."

Selain itu indikator yang lain adalah ketika para guru memberikan pertanyaan kepada para peserta didik dengan pertanyaan yang baru tapi dalam cakupan materi, rata-rata mereka dapat menjawabnya dengan baik meski sesekali mereka keliru dalam memberi jawaban.

Maka kesimpulanya adalah penerapan model pembelajaran Problem Based Learning dapat meningkatkan pemahaman peserta didik kelas VII MTs Mambaus Sholihin pada mata pelajaran fiqih, meski cara yang di gunakan dewan guru berbeda dengan teori yang ada tapi esensinya tetap sama.

\section{Faktor Pendukung dan Penghambat dalam Pelaksanaan Problem Based Learning pada mata Pelajaran Fiqih di Kelas VII MTs Mambaus Sholihin}

Yang namanya suatu kehidupan pasti di sana terdapat faktor pendukung atau faktor penghambat terhadap keberlangsungan kehidupan, begitu juga penerapan model pembelajaran problem based learning dalam mata pelajaran Fiqih di kelas VII Mts Mambaus Sholihin ini, tentunya dalam pengamatan penulis para dewan guru Fiqih seringkali menemukan faktor pendukung maupun faktor penghambat dalam menerapakan model pembelajaran ini, sehingga peneliti perlu untuk menguraikanya di sini dengan bahasa yang sesederhana mungkin. 
Sesuai data yang penulis dapatkan baik dari interview dengan beberapa informan dan di dukung dengan dokumentasi-dokumentasi yang ada, penulis dapat menyimpulkan bahwa:

\section{a. Faktor pendukung}

Dalam proses pelaksanaan model pembelajaran Problrm Based Learning di kelas VII MTs Mambaus Sholihin, ada beberapa hal yang menjadi faktor pendukung suksesnya proses pembelajaran dengan model ini di antaranya adalah;

1) Jumlah jam pelajaran yang lebih banyak dari pelajaran yang lain

Di MTs Mambaus Sholihin, Mata pelajaran Fiqih mempunyai porsi jam yang lebih banyak di bandingkan dengan mata pelajaran yang lain. Ini di karenakan Mata pelajaran fiqih adalah termasuk pelajaran prioritas madrasah. Sehingga pelajaran ini termasuk hal yang sangat di perhatikan dan menjadi pertimbangan utama dalam menaikkan peserta didik ke kelas selanjutnya.Inisesuai yang dituturkan WAKA Kurikulum Ustadz Nurul Huda

"Disini memang pelajaran fiqih menjadi pelajaran prioritas di madrasah ini karena pelajaran ini sangat penting untuk siswa dalam kehidupanya. Sehingga kami memberikanporsi jam pelajaran yang banyak guna mendukung suksesnya matapelajaran ini"

Oleh karenanya, jumlah jam yang lebih banyak dengan yang lainya ini memudahkan guru untuk penerapan model pembelajaran PBL ini karena sebagaimana maklum, PBL ini membutuhkan alokasi waktu yang banyak agar bisa berjalan sesuai rencana.

2) Mata pelajaran fiqih adalah mata pelajaran utama di MTs Mambaus Sholihin

Karena sudah menjadi mata pelajaran prioritas di madarasah ini selain Nahwu, Shorof, Bahsa Arab, dan Bahasa Inggris, maka faktor ini sangat mendukung suksesnya model pembelajaran ini untuk meningkatkan pememahan peserta didik dalam pelajaran fiqih, karena dengan model pembelajaran apapun para pserta didik di tuntut agar faham pelajaran ini. Apalagi dengan model PBL ini mereka merasa terbantu dan membuat mereka lebih muda memahami dari pada ketika ada guru yang mengajar hanya dengan model konvensional dan terkesan tidak ada inovasi dalam pembelajaran. 
b. Faktor penghambat

Selain faktor pendukung, para dewan guru juga sering menemukan kendala kendala atau penghamabat dalam melaksanakan model pembelajaran ini di antaranya adalah

1) Banyaknya peserta didik yang tidur saat mata pelajaran Fiqih terutama saat berada jam terakhir madrasah

2) Kurangnya motivasi peserta didik dalam mengikuti mata pelajaran Fiqih meski mata pelajaran ini sudah menjadi mata pelajaran utama

3) Banyaknya materi yang harus di tempuh dewan guru dalam tiap semester meski alokasi waktu sudah banyak tapi dalam pelaksanaanya masih kurang, sehingga menyulitkan guru untuk memilih antara kefahaman peserta didik akan pelajaran atau mengejar target yang sudah di tentukan madrasah.

4) Kitab yang dipakai pedoman adalah kitab salaf pesantren yakni Mabadiul Fiqh. Dewan guru biasanya pada dua jam pertama yakni $2 \times 45$ menit di gunakan untuk memberikan makna gandul/makna jawa di kitab tersebut dan menterjemahkanya ke dalam bahasa indonesia, proses ini membutuhkan waktu yang lama, karena tidak semua peserta didik mempunyai kemampuan untuk memaknai kitab dengan pegon.. sehingga ini menjadi penghambat terjadinya PBL yang efektif.

Faktor penghambat ini sesuai hasil wawncara kami dengan ustadz Subhan beliau mengisahkan ketika mengajar matapelajaran ini.

'Meski jam pelajaran yang dikasihpihak madrasah inibanyak, tapi rata-rata peletakanya di jam akhir sehingga membuat siswa sudah kelelahan sehingga takjarang kami dating anak-anak sudah pada tidur semua sehingga saya harus membangunkanya satu-satu. 'selain itu rata-rata mereka tidak begitu termotivasi untuk mengikuti pelajaran ini. Entah itu karena bosan atau apa. Pokoknya dari raut muka mereka kelihatan kalau mereka tidak ada gairah untuk mengikuti pelajaran ini"

Sedangkan menurut Ustadz Afif Al Khurni. Hal yang di sampaikan ustadz Subhan adalah sudah menjadi masalah klasik di madrasah ini. Menurut beliau hal yang menjadi penghambat adalah banyaknya materi yang harus di tempuh dewan guru dalam tiap semester meski alokasi waktu sudah banyak tapi dalam pelaksanaanya masih kurang, sehingga menyulitkan guru untuk memilih antara kefahaman peserta didik akan pelajaran atau mengejar target yang sudah di tentukan madrasah. 


\section{Upaya Yang Di Tempuh Guru Mata Pelajaran Fiqih Dalam Mengatasi Fator Yang Menghambat Proses Pembelajaran Dengan Model PembelajaranProblem Based Learning di MTs Mambaus Sholihin}

Dalam proses interaksi belajar mengajar, guru adalah orang yang memberikan pelajaran sedangkan siswa adalah orang yang menerima pelajaran. Dalam mentransfer pengetahuan kepada siswa diperlukan pengetahuan, kecakapan atau keterampilan sebagai guru. Tanpa ini semua tidak mungkin proses interaksi belajar mengajar dapat berjalan secara kondusif. ${ }^{10}$ Apabila terdapat beberapa faktor penghambat dalam pelaksanaan belajar mengajar tersebut, maka seorang guru seyogyanya peka dan terampil dalam mengatasi faktor penghambat tersebut.

Seperti yang sudah di lakukan oleh para dewan guru fiqih MTs Mambaus Sholihin, mereka menerapkan beberapa trik-trik untuk mengatasi hambatan yang ada saat melakukan pembelajaran dengan menggunakan model pembelajaran $\mathrm{PBL}$ ini.

Diantara trik-trik yang bisa penulis simpulkan adalah sebagai berikut

1. Memberikan hiburan terlebih dahulu saat sebelum melakukan pelajaran agar peserta didik merasa rileks dan bisa mengikuti pembelajaran dengan serius. Biasanya beliau memberikan video-video lucu.

2. Memberikan ketegasan kepada peserta didik yang tidak menyimak pelajaran dengan serius.

3. Memberikan hadiah atau reward kepada peserta didik yang bisa menjawab pertanyaan dengan benar agar semakin termotivasi dalam belajar

4. Meringkas materi pembelajaran yang sesuai dengan kebutuhan peserta didik. Ini bertujuan agar peserta didik langsung mempraktikanya dalam kehidupan. Karena terkadang tidak semua materi bisa langsung di praktekkan.

5. Guru menyiapkan masalah-masalah yang unik dan aneh agar membuat oeserta didik lebih tertarik

Trik-trik di atas kami dapatkan dari hasil wawncara kami dengan ustadz Subhan dan Ustadz Afif, Masing-masing mereka mempunyai cara-cara sendiri untuk mengatasi masalah tersebut.

Ustadz Subhan menuturkan.

'Yang kami lakukan adalah dengan memberikan hiburan terlebih dahulu saat sebelum melakukan pelajaran agar peserta didik merasa rileks dan bisa mengikuti pembelajaran dengan serius. Biasanya saya memberikan video-video lucu. Kadang juga saya memberikan ketegasan kepada peserta didik yang tidak menyimak

\footnotetext{
${ }^{10}$ Djamarah, Prestasi Belajar................. hlm. 32
} 
pelajaran dengan serius. Juga dengan memberikan hadiah atau reward kepada peserta didik yang bisa menjawab pertanyaan dengan benar agar semakin termotivasi dalam belajar'

Sedangkan yang dilakukan ustadz Afif Al Khurni adalah, beliaumengatakan

'yang biasa kami lakukan ketika terejadi hambatan dalam mengajar adalah dengan meringkas materi pembelajaran yang sesuai dengan kebutuhan peserta didik. Ini bertujuan agar peserta didik langsung mempraktikanya dalam kehidupan. Karena terkadang tidak semua materi bisa langsung di praktekkan. Selain itu kami menyiapkan masalah-masalah yang unik dan aneh agar membuat peserta didik lebih tertarik'

Dari paparan di atas, penulis bisa menyimpulkan bahwa suatu proses pembelajaran apapun modelnya, para guru di tuntut harus lebih kreatif, inovatif dan sebisa mungkin membuat siswa bahagia dalam mengikuti proses pembelajaran. Begitu juga dalam menerapkan model pembelajaram PBL ini, selain harus kreatif, inovatif dan sabar, guru juga harus menyiapkan materi seringkas mungkin dan menyiapkan masalah-masalah yang dapat merangsamg siswa agar semangat dalam mengikuti proses pembelajaran.

\section{Pemahaman Peserta Didik Kelas VII Setelah Di Terapkanya Model Pembelajaran Problem Based Learning Pada Mata Pelajaran Fiqih.}

Setelah para dewan guru Fiqih menggunakan model pembelajaran ini dalam mengajar mata pelajaran fiqih, sesuai data yang di dapatkan peneliti dari berbagi informan ataupun observasi yang di lakukan peneliti, kami menyimpulkan bahwa model pembelajaran problem based learning sangatlah membantu para peserta didik dalam memahami materi. Materi yang sebelumnya terkesan rumit bisa menjadi mudah dengan menggunakan model pembelajaran PBL ini. Ini di karenakan dewan guru telah menyederhanakan materi sehingga materi dapat di fahami dengan mudah oleh para peserta didik.

Sebagai bukti penunjang dari keberhasilan model pembelajaran ini dalam meningkatakan kualitas pemahaman peserta didik, sesuai data yang di dapatkan penulis, hampir dari mereka mendapatkan nilai yang lebih baik dari sebelumnya meski kenaikan nilainya tidaklah seberapa. Juga sesuai berita yang penulis dapatkan dari dewan guru, bahwa pesertan didik rata-rata mampu menjawab pertanyaan yang di lontarkan dewan guru dengan baik meski sesekali peserta didik salah dalam menjawabnya tapi masih dalam taraf kewajaran. 


\section{Kesimpulan}

Dapat disimpulkan model pembelajaran PBL yang di terapkan di MTs Mambaus Sholihin telah berjalan sesuai teori dan definisi meski agak sedikit berbeda dalam langkah-langkah. Namun begitu, esensi dari langkah-langkah PBL yang di lakukan para guru Fiqih MTs Mambaus Sholihin tetaplah sama dengan esensi yang di rumuskan para ahli yakni bisa melakukan proses pembelajaran berdasarkan masalah dan menuntut peserta didik lebih aktif dalam berpartisipasi dalam proses pembelajaran.

Suatu proses pembelajaran apapun modelnya, para guru di tuntut harus lebih kreatif, inovatif dan sebisa mungkin membuat siswa bahagia dalam mengikuti proses pembelajaran. Begitu juga dalam menerapkan model pembelajaram PBL ini, selain harus kreatif, inovatif dan sabar, guru juga harus menyiapkan materi seringkas mungkin dan menyiapkan masalah-masalah yang dapat merangsamg siswa agar semangat dalam mengikuti proses pembelajaran.

Sebagai bukti penunjang dari keberhasilan model pembelajaran ini dalam meningkatakan kualitas pemahaman peserta didik, sesuai data yang di dapatkan penulis, hampir dari mereka mendapatkan nilai yang lebih baik dari sebelumnya meski kenaikan nilainya tidaklah seberapa.

\section{DAFTAR PUSTAKA}

Abdul Majid. 2012. Belajar dan Pembelajaran Pendidikan Agama Islam. Bandung. Remaja Rosdakarya.

Djamarah, Bahri Syaiful. Djamarah. 1994. Prestasi belajar dan kompetensi guru. Surabaya: Usaha Nasional

Jamal Ma'mur Asmani. 2013. Tips menjadiguruinspiratif. kreatif dan inovatif. Jogjakarta: Diva-press.

Lexy J. Moloeng. 2004. Metodologi Penelitian Kualitatif. Bandung. Remaja Rosdakarya.

Miftahul huda. 2013. Model-Model Pengajaran Dan Pembelajaran. Yogyakarta. Pustaka Pelajar. 
Undang-undang Republik Indonesia Nomor 20 Tahun 2003 Tentang Sistem Pendidikan Nasional Tahun 2003. Bidang DIKBUD Tokyo.

Wina Sanjaya. 2013. Penelitian Pendidikan; Jenis. Metode. Dan Prosedur. Jakarta. Kencana. 
Saeful Anam dan Ahmad Amiq Fahman

220 | Kariman, Volume 08, Nomor 02, Desember 2020 